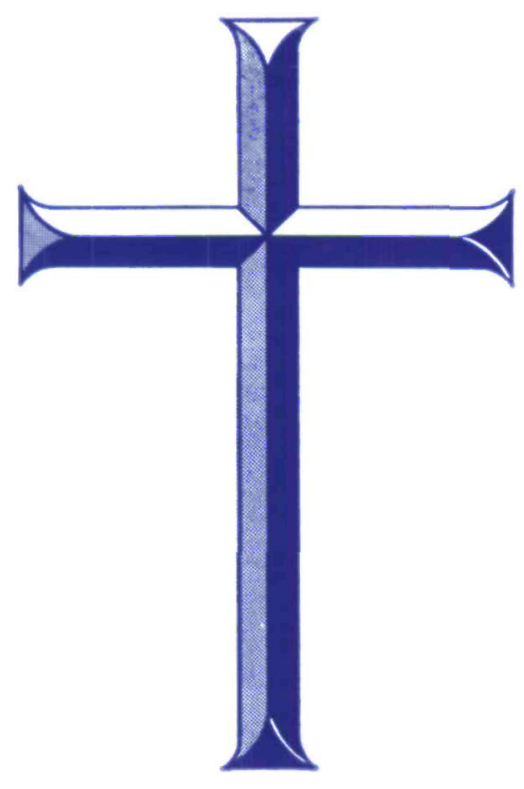

\title{
SCOTTISH JOURNAL
} OF

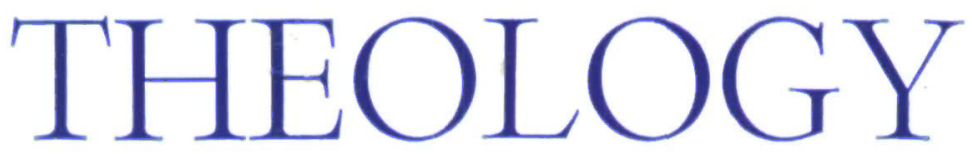

SGOTTISH ACADEMIC PRESS 


\title{
SCOTTISH JOURNAL OF THEOLOGY
}

\author{
EDITORS
}

Very Rev. Prof. T. F. Torrance, M.B.E., D.Litt., D.D., D.Théol., Dr Theol.

Rev. Prof. J. K. S. ReID, G.B.E., T.D., D.D.

\author{
ASSOCIATE EDITORS
}

Rev. A. I. C. Heron, M.A., B.D., Dr Theol.

Rev. J. Houston, M.A., B.D., D.PhIL.

CONSULTING EDITORS

Rev. Prof. R. S. Barbour, M.C., M.A., B.D.

Rev. Prof. Ian Pitt-Watson, M.A., B.D.

Rev. Prof. Robert Davidson, M.A., B.D.

Rev. Bastl Hall, M.A., Ph.D., D.D., F.S.A.

DIRECTORS

The above-named together with

Mr Douglas Grant, F.R.S.E., Chairman of Directors

Rev. Duncan B. Forrester, M.A., B.D. Rev. J. Heron, M.A., B.D., S.T.M.

Rev. Brian Smith, M.A., B.A., M.LitT. Rev. Prof. J. B. Torrance, M.A., B.D.

Rev. Prop. R. S. Wallage, M.A., B.Sc., Ph.D.

Rev. A. J. M. Wedderburn, M.A., B.D., Ph.D.

Mr A. James McGregor, G.A., Secretary

\section{EDITORIAL POLIGY}

A Bi-monthly Journal of Theological Inquiry and Reconstruction edited and published in Scotland, Scottish Journal of Theology is a broadly based international and ecumenical publication aimed at establishing modern theology on a sound scientific basis which commands wide agreement. It publishes contributions of major theological and philosophical interest from the world's leading scholars and also carries articles on biblical and applied theology intended to help the preacher and teacher. It seeks to meet the needs of university, seminary and church through constant dialogue with sciences other than theology and by engaging in current issues, both by original thinking and by extensive reviewing of biblical and theological literature.

Since it was first issued as a Quarterly in 1948 to provide a forum for critical inquiry into the historic foundations of theology and fresh thinking for the future, Scottish Journal of Theology has come to play a considerable role in world-wide theological discussion and renewal, and has stimulated an increasing flood of important theological material of a creative kind.

\section{SUBSCRIPTIONS}

Scottish Fournal of Theology is published six times a year. The Annual Subscription, including postage, for Institutions is $£ 12.50$ $(\$ 32 \cdot 00)$ and for Individuals direct to the Publishers $£^{8 \cdot 50}(\$ 2 \mathrm{I} \cdot 00)$. Single issues $£_{2} \cdot 25(\$ 5.50)$ and $£_{1} \cdot 50(\$ 4 \cdot 00)$ respectively.

All correspondence relating to subscriptions should be addressed to The Journals Manager, Scottish Academic Press Ltd., 33 Montgomery Street, Edinburgh EH7 5Jx, Scotland, U.K. 